\title{
Effect of Fasting and Foliar Application with Urea on Egyptian lime Trees Productivity A- Leaf ammonium content, flowering, fruit setting and yield of lime trees
}

\author{
EL-Tanany M.M., Mervat S.M. Sourour and Enas A. Tayel ${ }^{1}$
}

\begin{abstract}
A field experiment was conducted during two successive seasons of 2005/2006 and 2006/2007 in private orchard located at Housh Essa area, Behera governorate, Egypt to study the influence of holding irrigation periods and foliar application with urea on leaf ammonium content, flowering, fruit set and the fruit yield of lime trees (Egyptian Lime, $C$. aurantifolia). The relationship between leaf ammonium content and flowering, fruit set and yield was also examined. The trees were divided into 4 groups with 9 trees per group replicates and the tested treatments were, T1: control treatment (Traditional holding irrigation for 15days). T2 (Holding irrigation for 30 days), T3 (Holding irrigation for 45 days) and T4 (Holding irrigation for 60 days). Within each group, three trees were sprayed with urea solution only once and other three twice, while the remaining, three trees were left without spraying as a control. The obtained results proved that holding irrigation period for $\mathbf{4 5}$ days with urea spraying twice was efficient in increasing the ammonium concentrations in lime leaves and produced the highest number of flowers / branch and fruit set / branch . The data also revealed that holding irrigation for 45 or 60 days with urea spraying twice; gave the highest fruit yield / tree comparing with holding irrigation period for 15 days and without urea spray (control treatments). Positive and significant correlation coefficients was noticed between leaf ammonium content and lime fruit yield, except, in the first season, after 15 days with urea application where the correlation coefficient was not significant
\end{abstract}

\section{INTRODUCTION}

Citrus is one of the most important horticultural crops in Egypt due to its high economic value especially through exportation. The total area occupied by citrus in 2007 was 394548 feddan and produced 3134179 tons of fruits. From such area, 40573 feddans are cultivated by Egyption lime (acid lime); representing about $10.30 \%$ of the total area of citrus and produced 324509 tons of fruits; representing about $10.35 \%$ of the total citrus production (Annual Book of Agricultural Statistics, 2007). Some citrus species growing in tropical and subtropical climates notably lemon, lime (C.aurantifolia), citron (C.medica) and pumello ( $C$. maxima) are capable of flowering continuously all year around, and rainfall or irrigation after a period of drought, can trigger a flush of flowering (Shalhevet and Levy (1990)). A common orchard management practice in lime culture in Sicily, Italy is forcing with holding irrigation for periods of 30 days or longer in summer in order to induce flowers in late summer when applying $\mathrm{N}$ fertilizers and then rewatering the trees; the bloom occurs shortly after resumption of irrigation.The fruits that will set from such flowers are harvested the following summer when prices are typically high (Barbera et al., 1985). Similarly, Sagee and Lovatt (1991) experimented on 16- year old 'Frost Lisbon' lemon tree to induc flower by waterdeficit stress. They found that the increase in leaf ammonium content paralleled the duration and severity of the stress was correlated with floral intensity. They added that a cause and effect relationship between tree ammonium status and floral intensity was established by subjecting trees to minimal stress and artificially raising the ammonium content of the trees by foliar application of low-biuret urea at the end of minimal stress treatments. They concluded that foliar application with urea during water-stress treatment to citrus trees, may increase the ammonia status of the trees over the level accumulating in response to water-deficit stress only and resulted in increasing flowering, fruit set and yield. Moreover, Southwick and Davenport (1986) reported that 2 weeks of holding water resulting in plants with means predawn leaf water potentials of $0.9 \mathrm{MPa}$ and midday leaf water potentials of -2.25 $\mathrm{MPa}$, sufficiently induced flowering in 'Tahiti' Lime. While, sever water deficit resulting in $-3 \mathrm{MPa}$ for 20 days followed by 40 or 50 days of moderate water deficit (-2MPa) followed by foliar application of lowbiuret urea induced flowering in 16- year old 'Forst Lisbon' lemon trees. However, severe water deficit for only 30 days $(-3 \mathrm{MPa})$ did not effectively induce flowering. Maximum flowering was achieved at 4 weeks after resuming full irrigation . This phenomenon and cultural practice were used as approach with lime trees to obtain high production.

Because the fasting trees yield was very little, holding irrigation and foliar application with urea could increase lime fruit yield in the following summer season with high price and achieved highly economic income. 
So there is a need to determine the proper time and duration of preventing irrigation, also, determine urea spray date and the concentration of urea solution. Therefore the objective of the present study is to investigate the effect of holding irrigation periods and foliar application with urea on leaf ammonium content, flowering, fruit set and yield of Egyptian lime (Citrus auantifolia)

\section{MATERIALS AND METHODS}

The present investigation was conducted in a private orchard located at Ganabha village, Housh Essa Centre, Behera governorate, Egypt during two successive seasons of 2005/2006 and 2006/2007 on eight years old lime trees (Citrus aurantifolia, L.) budded on sour orange rootstock grown in clay Loam soil and planted at five meters apart. The selected trees were nearly uniform in vigour and size and receiving the same cultural practices usually adapted for this area according to the recommendations of Ministry of Agriculture, Egypt. Besides, in late summer during July and August months, most farmers in this area prevent the irrigation for fifteen or twenty days (used as a control treatment). Before reirrigation another time, each tree received $12 \mathrm{~kg}$ organic manure, $1.0 \mathrm{~kg} \mathrm{~N}$; in the form of ammonium nitrate $(33.5 \% \mathrm{~N}), 1.0 \mathrm{~kg}$ calcium super phosphate " $\left(15.5 \% \mathrm{P}_{2} \mathrm{O}_{5}\right)$ and $1 / 2 \mathrm{~kg}$ sulphur. The trees were surface irrigated with Nile water every 10 or 12 days during the growing season; from February to May.

Thirty six trees as uniform as possible were chosen for this study and the trees were divided into 4 groups each replicate had three trees and the treatments are presented as follows:

1) First group; holding irrigation for 15 days; from July, 5 to July, 20 (as a control treatment).

2) Second group; holding irrigation for 30 days; from July, 5 to 5 August.

3) Third group; holding irrigation for 45 days; from July, 5 to 20 August.

4) Fourth group; holding irrigation for 60 days from July, 5 to 5 September; Within each group; trees sprayed with urea only once (on July, 5), twice (on July, 5 plus August, 5) and trees were left unspray as control.

Each spray treatment was achieved by spraying the foliage of the trees until the drip point of the solution using a 20 litres hand sprayer. Each tree received 6.5 litres from the spray solution; i.e $65 \mathrm{gm}$ urea per tree every spray. Commerical urea with low- biuret $(46.5 \mathrm{~N} \%)$. Guard rows were left around the trees of each spray treatment. Different treatments were repeated on the same trees for the two successive experimental seasons.

\section{A. Tissue analysis:}

A leaf sample of 20-40 mature leaves was taken from non-fruiting shoots of the previous spring growth flushes. The leaves were collected from allover the circumference of each tree. Leaf samples were taken after 15 and 30 days from urea application date. The leaf samples were washed with tap water, rinsed three times in distilled water, oven dried at 65$70 \mathrm{C}$ to a constant weight and grounded to 20 mesh size. The leaf samples were used for ammonium determination. Ammonium was extracted from $0.5 \mathrm{gm}$ of ground dry material using the procedure suggested by Ali and Lovatt(1995), and colorimeterically determined by Nesslar method according to the A.O.A.C (1985).

\section{B. Flowering and fruit set:}

Through The duration from August or September to February of 2005/2006 and 2006/2007 experimental seasons, two branches in two different directions (in north east and south west) were tagged from each tree. (the circumference of chosen branches was $4.0 \mathrm{~cm}$ ). The number of flowers on each branch in each season was recorded.

During both experimental seasons, number and percentages of setted fruits were recorded and calculated, respectively. The equation of fruit set percentage was as follow:

$$
\% \text { Fruit set }=\frac{\text { No. of fruit set }}{\text { Total No. of flowers }} \times 100
$$

\section{Fruit number and yield :}

In May of 2006 and 2007 seasons. Fruit number on each fasted tree was recorded and average fruit weight of 15 randomly selected mature fruits was recorded. Fruit yield of each experimental tree was then calculated as $\mathrm{kg}$ per tree.

The data were statistically analyzed using split plot design according to Snedecor and Cochran (1982); main plot was holding irrigation periods and the sub plot was foliar application with urea. As well as, simple correlation was done according to Steel and Torrie (1980) between leaf ammonium and the different parameters describing flowering, fruit set and yield.

\section{RESULTS AND DISCUSSION}

\section{Effect of holding irrigation periods and foliar application with urea on leaf ammonium content:}

Data concerning the effect of different holding irrigation periods on leaf ammonium content are presented in Table (1). The results showed that holding irrigation treatment for 45 days; in both seasons, gave the highest leaf ammonium 
concentrations compared with holding irrigation for 30 and 15 days (control) and the differences were significant. This response was noticed after 15 and 30 days from urea application. Likewise, holding irrigation period for 60 days had markedly higher leaf ammonium content than the control treatment. This was quite clear after 15 days from urea application; especially in the first season, Table (1).

With regard to foliar application with urea, the data in Table (1) revealed that urea spraying twice, in both seasons, gave the highest leaf ammonium concentrations in comparison with the control treatment (without urea), and the differences were statistically significant. This positive response was noticed in leaf samples collected after 15 and 30 days from urea application.

The interactions between holding irrigation periods for 45 or 60 days with urea spraying twice, generally; in both seasons, gave significantly higher interactions comparing with other interactions. This was clear after 15 and 30 days from urea application, especially in the first season of study, as shown in Table (2). These results agreed with Ali and Lovatt (1994 ). They tested using water deficit stress as an additional method for increasing the $\mathrm{NH}_{3}-\mathrm{NH}_{4}^{+}$status of 30 years-old Washington Navel orange trees. They also found that, water - deficit stress markedly increased the ammonium status in the trees and also increased flowering, fruit set and yield. In addition, Lovatt and Cheng (1990), Ali and Lovatt (1992), Davies and Albrigo (1994) and Lovatt et al (1994) reported that foliar application of urea significantly raised the $\mathrm{NH}_{3}-\mathrm{NH}_{4}^{+}$content in Washington Nevel orange leaves. They added that maximum leaf ammonia content and de novo synthesis of arginine occurred after raising the leaf ammonia . They increased the leaf ammonia content of the trees artificially by application of low-biuret urea to the foliage just prior to flower initiation .

\section{Effect of holding irrigation periods and foliar application with urea on flowering behaviour:}

It was clear from Table (3) that holding irrigation for 45 days gave the highest number of flowers per branch during both seasons. However, holding irrigation for 15 days (as a control) produced the lowest number of flowers/branch and the differences were statistically significant. No significant differences were noticed between holding irrigation either for 45 or 60 days, in the second season, in this respect.

As for the influence of foliar sprays with urea on number of flowers, the data listed in Table (3) generally indicated that twice urea spraying twice during July and August gave the highest number of flowers/branch when compared with control (un sprayed with foliar urea) and the differences were significant.

The interaction between holding irrigation period for 45 days and spraying twice with urea, in both seasons, resulted in a higher number of flowers/branch comparing with the other different interactions. Similar result was also obtained between holding irrigation period for 45 days and without foliar application with urea; especially, in the second season, however, Table (4). In general, revealed that the interaction between holding irrigation treatment either for 15 or 30 days with or without spraying with urea gave the lowest number of flowers / branch.

The relation between leaf ammonium and total number of flowers, fruit set number and fruit set percentages was statistically examined by calculating the correlation coefficient between these variables as shown in Table 5. The correlation coefficient between leaf ammonium and flower number on lime trees, in the first season, was positive and significant, while in second season, it was not significant. This relation hold valid between flower numbers and ammonium content of leaves collected after 15 and 30 days from foliar urea application. This result seemed to be in agreement with those reported by numerous investigators. For example, Nevin and Lovatt (1987), Lovatt and Cheng (1990) and Davies and Albrigo (1994) all pointed out that floral intensity in citrus trees could be increased by raising leaf ammonium content with foliar application of urea. In addition, Pire and Rojas (1999) studied the effect of drought stress (irrigation was held for 8 or 12 weeks) and urea sprays (O or $5 \%$ ) on flowering of Tahiti lime. They found that the flowering response was increased with level of drought stress. Likewise, Lovatt et al (1988) on 16 years old Lisbon lime trees, Nevin and Lovatt (1987) using some citrus species and Almaguer - Vargas et al (1997) on Navelina orange trees, they found that degree of flowering was dependent on the severity of stress and on the accumulation of ammonia when subjecting trees under water-deficit stress for 50 or 60 days and then re-irrigated. They concluded that maximum flower number has been achieved under the conditions of minimal stress response to accumulate ammonia content of the trees and its artificially increasing by foliar application of low-biuret urea. Moreover, Nir et al (1972) studied of Eureka lime flower bud differentiation during the drought treatments and before re-irrigation and suggested that the influence of water stress may inhibit production of $\mathrm{GA}_{3}$ gibberellin in water stressed root system. They 


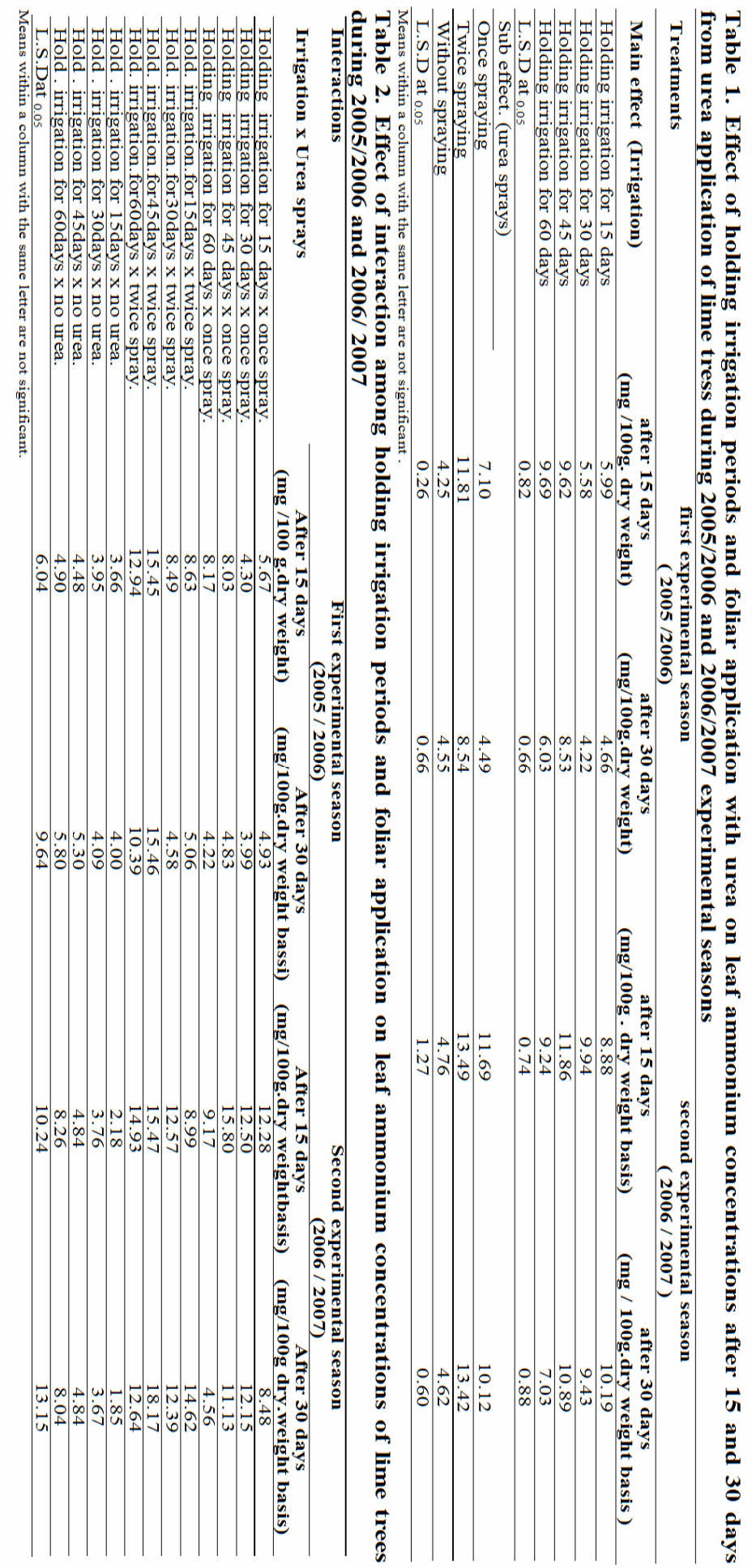




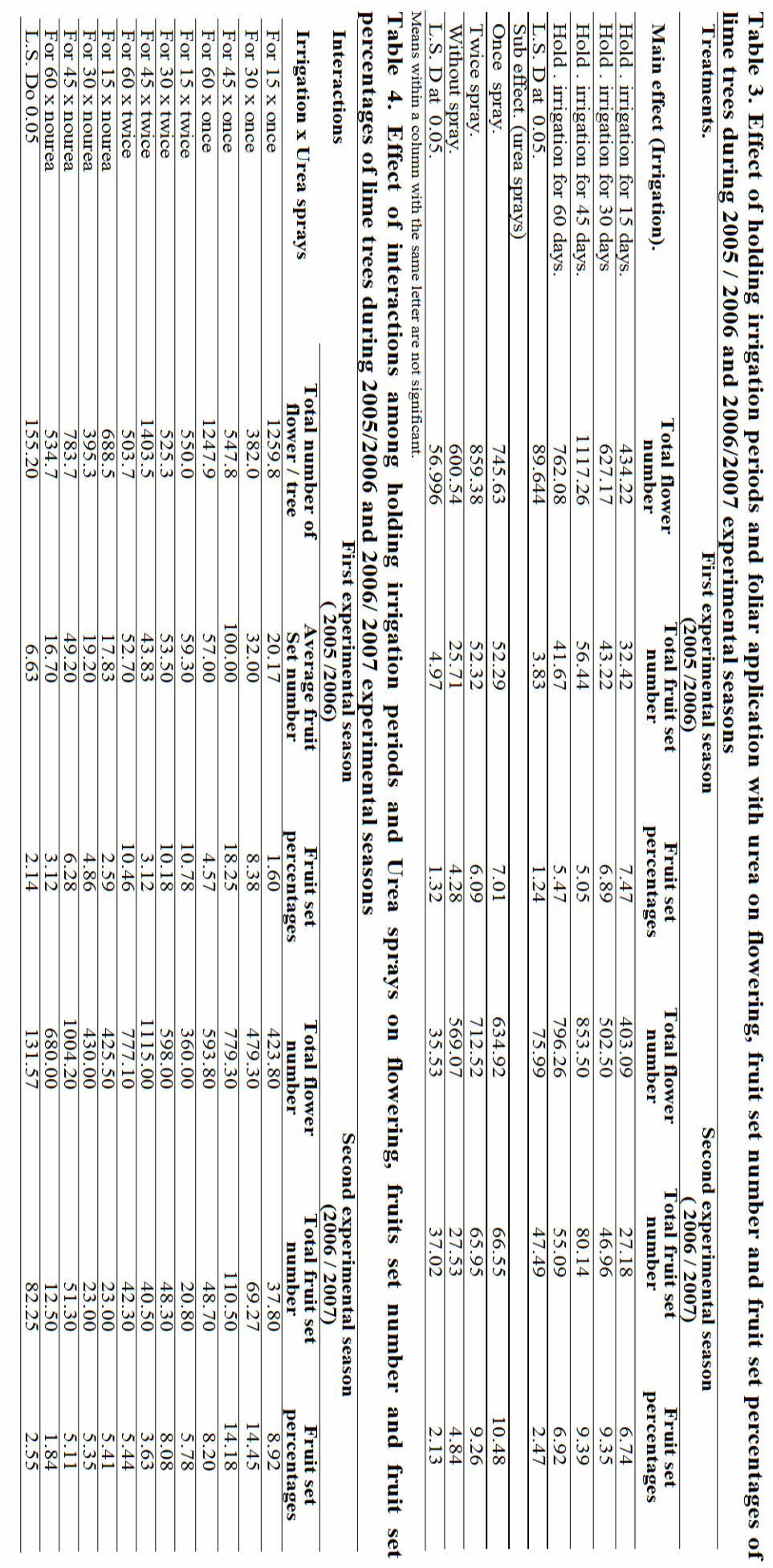


added that amount of stress is necessary to induce flowering. In addition, Barbera et al (1981) and Monselise (1985) mentioned a common orchard management practice of lime culture in Sicily, Italy; i.e forcing withholing irrigation during the summer months and then applying $\mathrm{N}$ fertilzer when rewatering. They reported that the bloom occurs shortly after resumption of irrigation. Also concluded that the magnitude of stress- induced flowering increase when $\mathrm{N}$ was supplied at the end of the stress period.

\section{Effect of holding irrigation periods and foliar application with urea on fruit set:}

Data concerning the effect of different holding irrigation periods on number of fruit set/branch showed that the same treatment which increased both leaf ammonium concentrations and number of flowers, also increased fruit set number . In both seasons, the highest number of fruit set was obtained when irrigation was held for 45 days Table (3). It was clear that holding irrigation period for 15 days (as a control) induced lower fruit set during both seasons of study and the differences with other treatments were significant. The results of fruit set percentages, presented in Table (3) revealed the same trend as that of fruit set number/ branch, especially in the second season; where holding irrigation for 45 days, gave the highest percentages of fruit set when compared with the control treatment. However, the highest percentages of fruit set was obtained from holding irrigation periods either for 15 or 30 days during first season of study.

With regard to the influence of foliar application with urea on number of fruit set and percentages/ branch, the results in Table(3), generally indicated that spraying once with urea; in July or twice; in July plus August, in both seasons, produced the highest number and percentages of fruit set/ branch when compared with the control trees; and the differences were significant.

As for the interaction between holding irrigation periods and foliar sprays with urea on fruit set; expressed as number or percentages; the results in Table (4) generally revealed that holding irrigation for 45 days with spraying once with urea, in both seasons, gave the highest fruit set number and percentages per branch compared with other interactions and the differences were significant. On the contrary, the lowest interaction was obtained when irrigation was held for 60 days without urea spraying or with holding irrigation for 15 days with once urea sprayed.

The correlation analysis between leaf ammonium built up from foliar application with urea or holding irrigation periods and fruit set number might support such notation. Positive and significant correlation coefficients were observed between ammonium content of leaves collected after 15 days from urea application and the number of fruit set during both seasons of study, Table(5). The correlation coefficient between leaf ammonium content and the fruit set percentage, especially in the second year of study was positive and highly significant. On the contrary, this relation was negative and not significant after 30 days from urea application in the first season.

The results obtained herin, generally are in agreement with those reported by Domingo et al (1996) using regular deficit irrigation on limes. They concluded that a moderate deficit irrigation during fruit set and rapid fruit growth period, did not result in fruit set reduction or yield . They also added that regular deficit irrigation did not significantly reduce fruit set and yield but delayed maturity in limes. Similarly, Goldhamer and Viveros (2000) working on almond trees showed that water- deficit irrigation in early season, increased fruiting density in almond trees. On the other hand, Gonzlez - Altozano and Castel (1999) using'Nules Clementine' revealed that there were large differences in Clementine trees sensitivity to water stress during different phenological stages. They concluded that flowing and fruit set phase was the most critical. Likewise, Mostert (1999) and Ginestar and Castel (1996) studied the effect of water stress on 'Valencia' and 'Clementine performance during flowers and fruit set stages (phase I). They found that dry treatments had a negative effect on flowering and fruit set phase. On sweet lime, also, Arora and Yamdagni (1986) found that foliar nitrogen treatments; once or twice, increased fruit set and final fruit retention. In the same directional, Ali and Lovatt (1994) reported that ammonium or it metabolites might have a positive influence on flower production and on subsequent ovary development and set in citrus orchards. As well as, Ali and Lovatt (1992) found that foliar application of urea at the rate of $0.15 \mathrm{~kg} \mathrm{~N} /$ tree on citrus trees may sufficient augment ammonia accumulation to increase flowering and /or fruit set as well as the tree's yield.

\section{Effect of holding irrigation periods and foliar application with urea on fruit yield:}

The data concerning the effect of holding irrigation periods on fasting fruit yield; expressed as fruit number and fruit weight ,in both seasons, showed that holding irrigation treatments for 45 days and 60 days produced the highest fruit yield per tree; expressed as fruit number or weight, in comparison with holding irrigation treatments for 15 or 30 days which gave a lower fruit yield per tree 


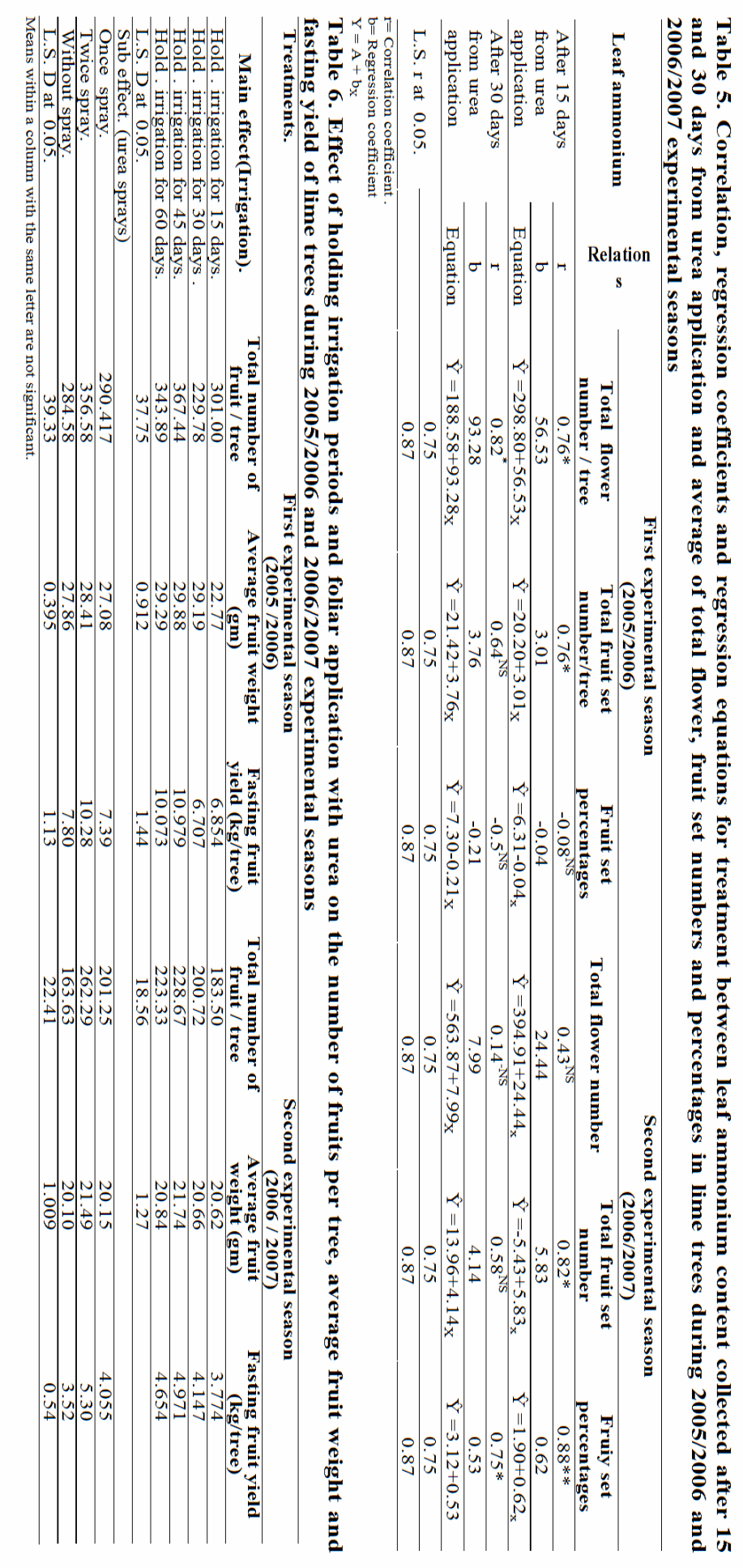




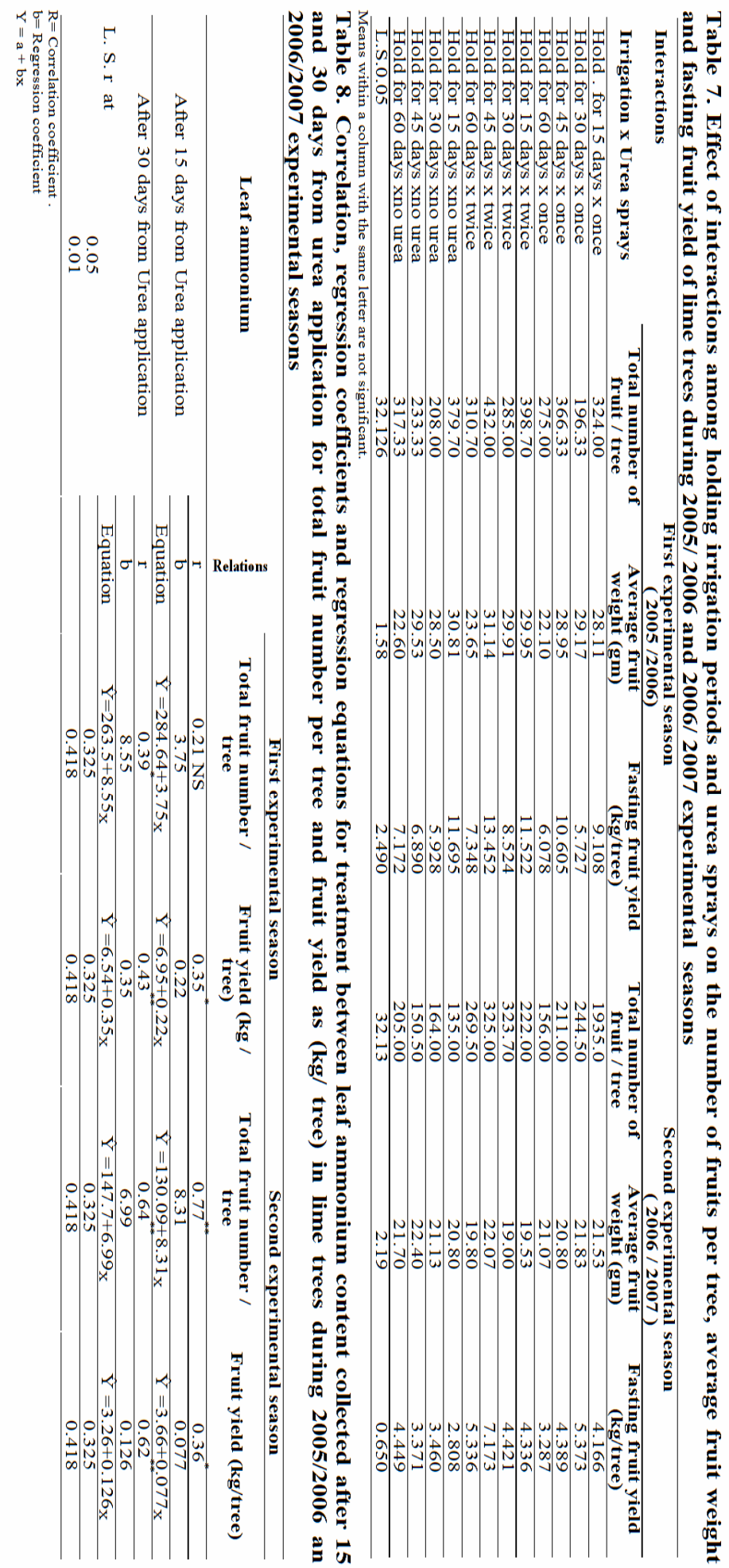


(weight or number), such result, was supported by statistical significant differences Table (6), Generally, no significant differences were observed in average fruit weight among the four holding irrigation treatments, particularly in the second season, as shown in Table (6).

The data concerning the influence of the different urea spraying treatments on fruit yield expressed as weight or number are presented in Table (6). In general, the data of the present investigation indicated that trees sprayed with urea twice (in July and August), in both per trees seasons, produced the highest fruit yield per tree; expressed as average fruit number or weight in comparison with Lime trees sprayed with urea only once or trees control treatment and the differences were statistically significant.

The interactions among different holding irrigation periods with foliar urea sprays, generally showed that, holding irrigation period for 45 days and urea spraying twice treatment, in both seasons, produced significantly higher fruit yield per tree compared with the other different interactions (Table 7). On the other hand, the interaction between holding irrigation for 30 days with no foliar urea; gave the lowest fruit yield per tree, especially in the first season, as well as holding irrigation treatment for 15 days with no foliar urea, in the second season, gave the same trend. The correlation analysis between leaf ammonium built up either urea sprays or holding irrigation treatments and fruit yield (weight and number) might support such notation . Positive and highly significant correlation coefficients between these two variables. This relation hold valid between fruit yields (weight or number) and the ammonium content of leaves collected after 15 and 30 days from foliar urea application during both seasons of study. The only exceptional case, was in the first season, after 15 days from urea application; the correlation coefficient was not statistically significant, Table (8). The forecited results seemed to be in agreement with those reported by Domingo et al (1996) using regulated deficit irrigation on lemons, they concluded that moderate deficit irrigation during rapid fruit growth period, did not result in yield reducition. They added that reducing irrigation during the rest of season, resulting in a saving of $30 \%$ of water, did net affect yield. Similarly, Hilgeman (1977) and Goell et al (1981) affected, reported that water deficit stress affected vegetative growth sooner in citrus trees than its effects on fruit yield or size and moderate stress reduced trunk enlargement and canopy growth but had no significant effect on average yield or final fruit size . Moreover, Gonzalez-Altozaro and Castel (1999) stated that the most appropriate time for deficit irrigation of
'Clementine' mandarins was in summer when water saving of $7 \%$ to $14 \%$ did not cause negative effects on yield, fruit size or quality. As well as, Goodall and Silviera (1981) studied the effect of the drought treatment before irrigation resumed on'Bears' lime production. They found that the verdelli crop amounted to only $13 \mathrm{~kg}$ per tree, or $<10 \%$ of total annual production. In opposite side, Romero et al (2006) reported that cumulative fruit yield decreased more in deficit irrigation trees budded on 'Carrizo' $(40 \%)$ than on 'Cleopatra' (27\%). The yield component most affected by deficit irrigation in 'Cleopatra' was the number of fruits, whereas in 'Carrizo' it depended on the severity of water stress.

As for the effect of foliar application with urea on average fruit yield; expressed as weight or number; EL-Otmani et al (2000) as well as, Lovatt (2000) found that foliar urea significantly increased fruit yield in Clementine mandarin and the increase in yield was due to an increase in fruit number per tree and in fruit size. In addition, Arora and Yamdagni (1986) found that sweet lime trees sprayed once or twice with urea showed marked increased in final fruit retention. Similarly, Kumar et al (1988) reported that urea sprays gave a greater fruit yield than water spray in lemon trees. Noteworthy, Rabe et al (1993) mentioned that Navel and Shamouti orange yield were markedly increased by urea spray in comparison with unsprayed control. Also, Farooqu and Rajwana (2008) experimenting on Balady mandarin and Navel orange trees. stated that with increasing urea concentration up to $2 \%$ resulted in a progressive increase in the tree yield. Furthermore, urea sprays were found to have a stimulatory effect on the fruit growth which subsequently increased fruit weight.

The increment in fruit yield observed herein might be attributed to the influences of holding irrigation periods and urea sprays in raising the ammonium and arginine levels of lime trees and subsequently synthesis of polyamine; such as putrescine, via arginine, (Lovatt, (1999). Putrescine is well known to have a positive effect on the growth and development of ovaries and this increased fruit size and weight [Terence (1985) and Costal et al.,( 1984 )].

\section{CONCLUSION}

It could be concluded that holding irrigation period for 45 days with foliar application twice with urea at $1 \%$ in July and August to lime trees increased flowering, fruiting and fasting fruit yield. 


\section{RE FERENCES}

Almaguer- vargas, G.; J.Rodrigues-Alcazar; A.E. BecerrilRoman ans A.Larque- Saavedra (1997). Promotion of out-of season flowering through physical or chemical stress applied to orange trees in the greenhouse. Agrociencia, 31 (1): 51-58.

Annual Book of Agriculture statistic (2007). Study of important indicators of the Agicultural statistics vol.2 (Table 76). summer and Nile crops, August 2008. P. 309313.

Ali, A.G. and C.J. Lovatt (1992). Winter application of foliar urea. Citrograph , 78: 79.

Ali, A.G and C.J. Lovatt (1994 ) Winter application of low biuret urea to the foliage of Washington Navel orange increased yield . J. Amer. Soc. Hort. Sci ., 119 (6): 1144 1150 .

Ali. A.G. and C.J. Lovatt (1995). Evaluating analytical procedures for quantifying ammonia in leaf tissue . J.Amer . Soc . Hort . Sci ., 120 ( 5): 871 - 876.

A.O.A.C. (1985). Official methods of Analysis of the Association of Official Agricultural Chemists. Published by the A.O.A.C., 14th ed. Washington . D.C.

Arora, R.K. and R. Yamdagni (1986). Effect of different doses of nitrogen and zinc sprays on flowering, fruit set and final fruit retention in sweet lime (Citrus lmettioides, Tanaka). Haryana Agric. Univ. J. Res., 16 (3): 233-239, Indi. [Hort . Abst ., 57 (6) : 4969]

Barbera, G.; G. Fatta del Bosco, B.Locasio, and G. Occorosco (1981). Some aspects on water stress physiology of forced lime (C. lime) trees Proc. Int. Soc. Citric. (Tokyo) 2: 522 523.

Barbera, G.; G. Fatta del Bosco and B . Locascio (1985). Effects of water stress on lime summer bloom: The "Forzatura" Technique in the Sicilian citrus industry. Acta Hort. 171: $391-397$.

Costal, G.; R.Baraldi and N. Bagni (1984) Inflluence of putrescine on fruit set of apple (cv.Ruby Spur). Acta Hort., 149: 189- 191.

Davies, F.S. and L.G. Albrigo (1994). Citrus, C.A.B. International walling Bord Oxon Ox108 DE, UK.

Domingo, R.; M.C. Ruiz- Sanchez; M.J. Sanches- Blanco and A. Torrecillas (1996). Water relations, growth and yield of Fino lime trees under regulated deficit irrigation. Irr. Sci ;; $16: 115-123$.

EL-Otmani , M.; A.Ait - Oybabou; F.Z. Taibi ; B. Lamoufid ; C.J. Lovatt and M.EL-Hila (2000). Prebloom foliar urea application increased fruit set, size and yield of Clementine mandarin. Proc. Int. Soc. Citricult.

Farooqu, M.and I.A.Rajwana (2008). Early winter spray of Low- biuret urea improves marketable yield and fruit quality of sweet oranges. Pak. J. Bot., 40 (4): 1455- 1465.

Ginestar, C. and J.R. Costel (1996). Response of young Clementine citrus to water stress during different phonological periods . Hort. Sci. $71-551-559$.
Goell, A.; A. Golomb; D.kalmar; A.Mantell and S. Sharon (1981). Moisture stress-a potent factor for affecting vegetative growth and tree size in citrus. Proc Int. Soc. Citric (Tokyo), 2: 503-506.

Goldhamer, D.A. and M. Viveros (2000). Effects of preharvest irrigation cutoff durations and postharvest water deprevation on almond trees performance. Irr. Sci., 19: 125-131.

Gonzalez-Altozano, P. and J.R. Castel (1999). Regulated deficit irrigation in Clementine de 'Nules' citrus trees. Yield and fruit quality effects. Hort Sci. Biotechnol. 74: 706- 713 .

Goodal, G.E. and K.G. Silviera (1981). Adapting the Italian verdelli process to Persian lime production California. Proc. Int. Soc. Citric (Tokyo), 2: 518-520.

Hilgeman, R.H. (1977). Response of citrus to water stress in Arizona. Proc. Int . Soc . Citric (Orlando), 1: 70- 74.

Kmar, R;S. Ranvier and K.K. Misra (1988). Effect of growth regulators and urea sprays on the regulation crop in lime (Citrus limon Burm). Indian . J. Hort ., 45 (3- 4): $225-228$.

Lovatt C.J. (2000). Management of foliar fertilization . Terra, 17(3): $257-264$.

Lovatt, C.J. (1999). Timing citrus and avocado foliar nutrient applications to increase fruit set and size. Hort technology. October-December, 9(4): $607-12$.

Lovatt, C.J.; O.Sagee and A.G. Ali (1994). Ammonia and/ or its metabolites influence flowering, fruit set, and yield of the Washington Navel orange. Proc. 7th Intl. Soc. Citrus congr., 1: $412-416$.

Lovatt, C.J.and A.H.Cheng ( 1990 ) . Comparison of some aspects of nitrogen metabolism of avocado with citrus . Acta Hort.; No. $275: 489$ - 495.

Lovatt C.J.; Y.Zheng and K.D. Hake (1988) . A new look at the Kraus- raybill hypothesis and flowering in citrus Citriculture- Sixth international- Citrus - Congress,Middle- East,- tel- Aviv, - Isreal , - 6-11-March - 1988 - vol. 1:475-483.

Monselise, S. P. (1985). Citrus and Genera, P. 257 - 294. In: A.H.Halevy (ed.) CR Hand book of flowering, vol. 2 CRC Press, Boca Raton, Fla.

Mostert, P.G. (1999). Die invloed van water toediening sopsies op die produksie van sitrus. (Citrus sinensis var. Valencia) M.Sc. Ager. Thesis, Univ. of the orange free stat, Bloemfontein, South Africa .

Nevin, J.M. and C.J. Lovatt (1987). Deminstration of ammonia accumulation and toxicity in avocado leaves during water-deficit stress. Year book,- South African Avocado Growers Association. vol. 10: 51- 54.

Nir , I; R . Goren and B. Leshem (1972). Effects of water stress,gibberelic acid and 2-chloroethyl trimethylammonium chlorid (CCC) on flower differentiation in 'Eureka' Lime trees. J. Am. Soc. Hort. Sci. Vol. 97: 774-778. production California. Proc. Int. Soc. Citric (Tokyo), 2: 518-520 
Pire, R.and E. Rojas (1999). Effect of drought stress and urea sprays on production of flower and vegetative buds of Tahiti lime. Fruits- Paris., 54 (3): 177 - 182.

Rabe, E.; H.P.Van der Walt and H.P. Walt van der (1993). Effect of pre-blossom low-biuret urea sprays on yield improvement in specific citrus cultivar. Citrus J., 3 (4): 26-28.

Romero, P.; J.M. Navarro; J.Perez-Perez; F. Garcia- Sanchez; A.Gomez-Gomez L. Porras; V.Martinez and P.Botia (2006). Deficit irrigation and rootstock: Their effects on water relation, vegetative development, yield, fruit quality and mineral nutrition of Clemenulues mandarin. Tree physiology vol .26 (12): $1537-1548$.

Sagee, O. and C.J. Lovatt (1991). Putrescine content parallels ammonia and arginine metabolism in developing flowers of the Washington Navel orange. J. Amer. Soc. Hort. Sci., 116 (2): $280-285$
Shalhevet, J.and Y.Levy (1990). Irrigation of Agricultural crops - Agronomy Monograph,: 963.

Snedecor, G.W. and W.Cochran (1982) Statistical Methods. 7th Edition. Aiwa State Univ. Press. Amer. Aiwa. U.S.A pp. 507.

Southwick, S.M. and T.L. Davenport (1986). Characterization of water stress and low-temperature effects on flower induction in citrus. Plant physiol., 81: 26- 29.

Steel, R.G.D., and J.H. Torrie (1980). Principles and procedures of statistic: A biometrical approach Mc Graw- Hill book Co. New York

Terence, A.S. (1985). Polyamines. Ann. Rev. Plant Physiol., 36: 117- 143. 


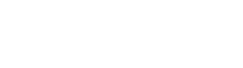

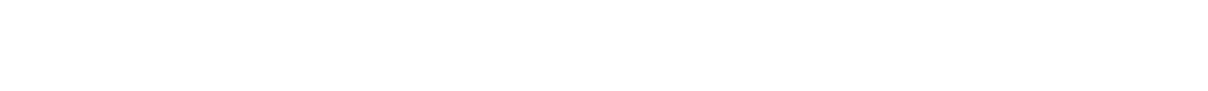

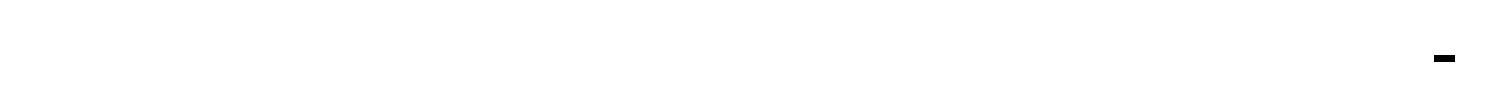

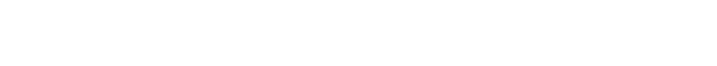

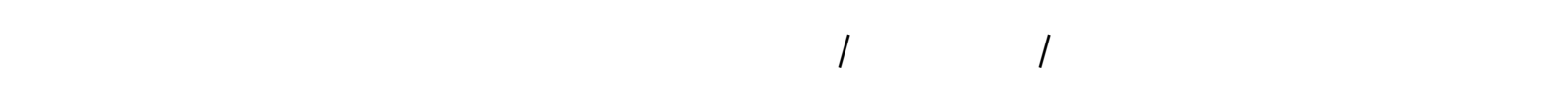

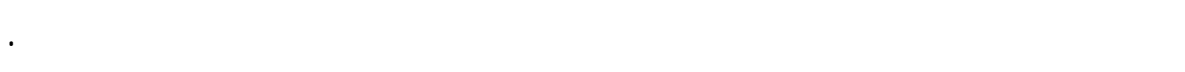

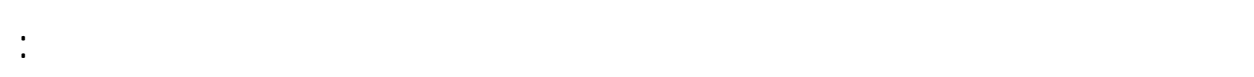

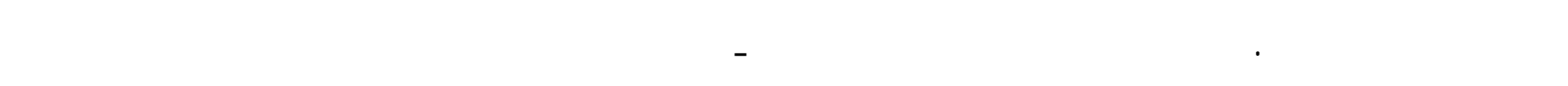

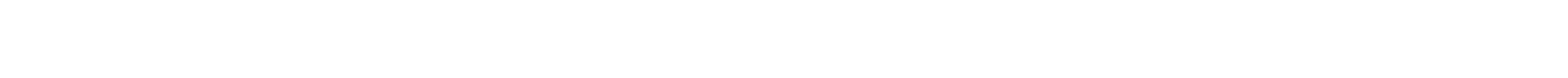

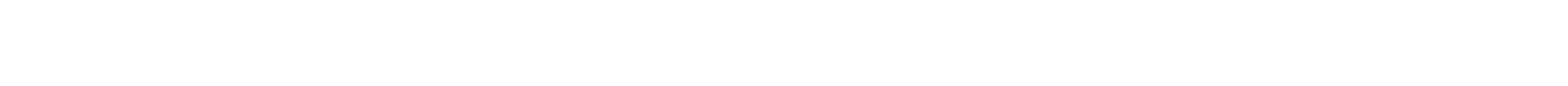

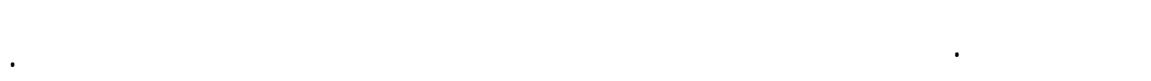

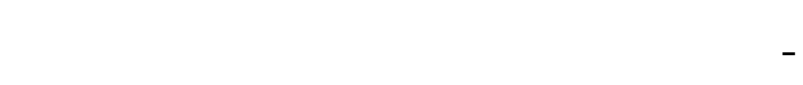
الأمونيوم والنزرم] وكقد الثمار والصصول.

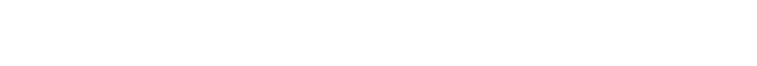

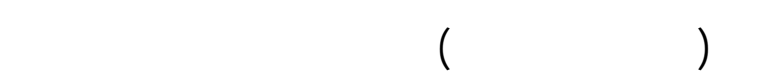
0 ايوم وبدون الشش باليوريا (كمعله كنترو).

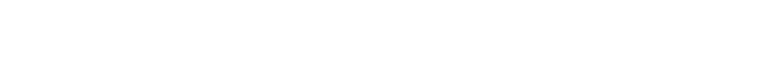

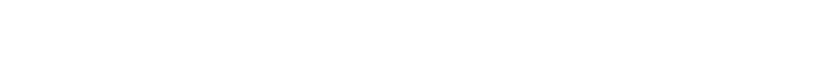

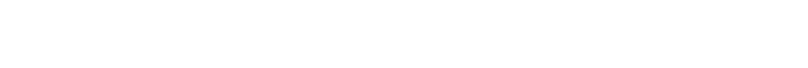

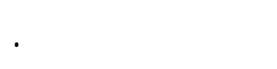

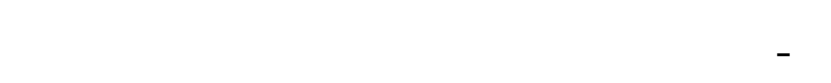

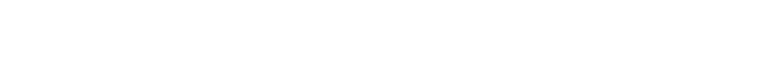

